\title{
Immigration and the competitiveness of an island tourism destination: a knowledge- based reputation analysis of Lanzarote, Canary Islands
}

\author{
Desiderio Juan García-Almeida \\ University of Las Palmas de Gran Canaria, Spain \\ dj.garcia@ulpgc.es
}

and

\author{
Esther Hormiga \\ University of Barcelona, Spain \\ ehormiga@ub.edu
}

\begin{abstract}
This paper sheds light on the relationship between immigration and tourism competitiveness on the island of Lanzarote through the analysis of reputation from the demand perspective. The tourists' knowledge about news on immigration from a destination, their contact with immigrants in the area, and the influence of the presence of immigrants there are studied, as all these factors can have a major impact on island competitiveness in tourism. The empirical work has been conducted with a survey of tourists on Lanzarote, Canary Islands, Spain. A total of 359 valid questionnaires were obtained. Results show a relatively low impact and retention of immigration news about the destination, and a low perceived contact with nonEuropean immigrants when visiting the island. Moreover, tourists tend to recognize the positive value created by immigrants on the island, though some negative effects are also indicated. Finally, immigration seems to have a positive impact on the tourist's global satisfaction and loyalty to the island destination.
\end{abstract}

Keywords: destination competitiveness, immigration, islands, Lanzarote, reputation, tourism

https://doi.org/10.24043/isj.13

(C) 2017 - Institute of Island Studies, University of Prince Edward Island, Canada.

\section{Introduction}

Immigration is considered one of the major determinants of European competitiveness for future years, along with education and R\&D policies (e.g., Huber et al., 2010). The arrival of newcomers from other countries generates new social dynamics in local contexts, and the influx of migrants has effects on the economic aspects of the host country. At the same time, the political debates in host countries about this topic are cyclical and controversial due to its potential effects, and the media coverage of this topic is high. Immigration has become one of the most discussed and controversial topics in recent public and political debates in many advanced economies (Drinkwater, 2010). These debates are exacerbated on islands, probably due to the perception of limited, isolated territory with a certain 'carrying capacity' for residents. However, Akee (2010, p. 323) indicates that "a lack of comprehensive data plagues immigration research."

Tourism is a strategic industry for many developed and developing islands. Many have tourism as the main default option for their economic development (Figueroa \& Rotarou, 2016). The characteristic complexities of island destinations result in many concerns, especially 
referring to the potential success of sustainable tourism development (Graci \& Dodds, 2010). The tourism sector is also deeply affected by migration, and the consequences and effects of this phenomenon are topics of interest for many stakeholders in the industry. Moreover, human mobility is linked to a complex and changing field of movements, which have significant implications for understanding sustainable tourism (Williams, 2013).

Due to the impact of globalization, the analysis of competitiveness in the tourism industry has focused not only on the business world but also on the destination arena (Kozac et al., 2010). The relationship between tourism and immigration has been increasingly analyzed in the last decade. Emerging from an under-studied stage (e.g., Feng \& Page, 2000), the intertwining patterns of migration and tourism have received much attention in the academic literature in recent years, due to the relevance and economic and social effects of both phenomena. Nevertheless, the specific global role that immigration can have on the development and competitiveness of a tourism destination through the impact on its reputation has not been empirically addressed, and it can provide relevant, data-based ideas for the political debate in many regions. Thus, the inhabitants of islands can fear that this reputation degrades due to high levels of immigration.

This article aims to shed light on how immigration affects tourism development and competitiveness on an island from a demand-based perspective. Lanzarote has been selected as the empirical setting since it is a Spanish island with a population consisting of nearly $30 \%$ immigrants in 2008 and an island on which the tourism industry is the main source of income generation and where sustainable development is a major concern. The specific goals of the work are (1) to analyze tourists' knowledge of immigration news about an island destination, (2) to study their contact with migrants on the island, and (3) to analyze the influence of immigrants on the island from the tourism demand perspective. By answering these questions, we expect to better understand the perceived relationship between immigration and development in insular territories with solid competitive bases in tourism. The paper's contributions would also allow for a better understanding of immigration so as to improve recommendations for island tourism development.

\section{Lanzarote as a case in point}

Lanzarote, a $845.9 \mathrm{~km}^{2}$ Spanish island in the Atlantic Ocean, has been selected as an empirical case. Several reasons support this choice. Lanzarote is one of the seven Canary Islands, and tourism is a paramount part of the island's economy. The beginning of mass tourism activities on Lanzarote in the last third of the 20th century improved living standards for the local population but also led to cultural changes (García-Rodríguez et al., 2016). In addition, the number of foreign nationals has significantly increased in Lanzarote in the last decade.

According to Bauer, Lofstrom, and Zimmermann (2000), Spain is a "new immigration country" like Italy and Ireland. Alvarez Alonso, Hernández Hernández, and Simancas Cruz (2005) indicate that during the last two decades of the 20th century Lanzarote was an island with a low level of unemployment and high rates of immigration, especially from Latin America but also from Europe and Africa. Data from the National Institute of Statistics (2016) states that at the end of 2008, Lanzarote had 136,445 inhabitants, and the population had grown $24 \%$ during the previous five years. Foreigners accounted for $27.86 \%$ of the total $(37,609$ individuals), up from $21.1 \%$ five years before (23,158 foreign nationals) and $13.1 \%(12.806)$ in 2001. In 2015 there were 31,638 foreigners living on Lanzarote out of 141,497 total inhabitants; many foreign nationals left the island due to the economic crisis, which affected all of Spain. As for immigration and jobs in the tourism industry, during the record year of immigration, $34.7 \%$ of foreign residents on the Canary Islands worked in the tourism sector (OBECAN, 2008). With data from all the Canary Islands, $49 \%$ of foreign employees in the 
tourism industry originally come from the Americas, $23.7 \%$ from Europe, 20\% from Africa, and $7.3 \%$ from Asia.

European islands have become points of transit and places of settlement for regular and irregular migrants, tourists, workers, and asylum seekers (Bernardie-Tahir \& Schmoll, 2014). Recent irregular maritime immigration in the Canary Islands has been an object of analysis due to the interest and impact of this phenomenon (Godenau, 2012). Thus, in recent years, immigration to Lanzarote in particular has been massive, and its proximity to the West African coast has fostered the arrival of thousands of immigrants, prompting a large degree of media coverage in Europe. The Canary Islands have been a preferred target destination for thousands of irregular migrants (Triandafyllidou, 2014): along with Lampedusa/Linosa (Italy), Malta, and the Aegean Islands (Greece), the Canary Islands have felt the effects of irregular migration from the 2000s up until today, with varying degrees of intensity and number of arrivals. Godenau (2012) describes how the Canary Islands experienced irregular maritime immigration from the West African coasts during the first decade of this century. Compared to other countries like Australia, Spain does not apply special migratory legislation to the islands included in its territory (Baldacchino, 2014).

Concerns about Lanzarote's international reputation and the need for adopting a sustainable strategic approach towards the sector have generated an interest in the destination's tourism competitiveness. Bernardie-Tahir and Schmoll (2014) state that irregular migration to southern European islands draws extraordinary media attention. These authors also indicate that this prominent visibility in media and political discourse is partly explained by the migrants' arrival in makeshift boats. Thus, the so-called 'cayuco crisis' in 2006 produced an institutional change in border management and the active involvement of the European Union (Godenau, 2012). The creation of detention centres in which immigrants were confined also increases the migration problem (Bernardie-Tahir \& Schmoll, 2014). Thus, the smallness of islands (King, 2009) may increase the sensation of crisis when the media report about the arrival of illegal immigrants. Though many people equate islands with vacation, relaxation, and having a nice time (King, 2009), many locals feared that their island's reputation could be tarnished by news depicting a situation that resembled a humanitarian crisis.

According to the regional data of passengers arriving in Lanzarote, the total number of tourists in 2008 was $2,187,308$, a number that rose to 2,640,862 in 2015. Lanzarote is considered a 'sun and beach' destination (Beerli \& Martín, 2004) and its reputation as a sustainably developing island was recognized in 1993 by UNESCO, which declared the island a Biosphere Reserve. Nevertheless, according to Beerli and Martín (2004), first-time tourists on Lanzarote wish to rest, escape from routine, alleviate stress, and get to know new and different places.

Residents' attitudes towards tourism play a fundamental role in directing its development (Figueroa \& Rotarou, 2016). On Lanzarote, residents are very aware of the relevance of tourism for the island economy, but also of the frailty of the territory. The ecological awareness awakened by César Manrique, a famous multifaceted native artist with a strong orientation towards sustainable development, is still prevalent on the island. Despite the artist's death in 1992, his tourism constructions and attractions (such as the grotto of the Jameos del Agua or the peasant's house) have left an enduring impression on the locals, allowing for the retention of his aesthetic philosophy paired with his views on protection and safeguarding of the natural landscape and the local heritage. As Chen, Chen, and Lee (2011) indicate in the context of small islands which are difficult to access, the island's attractions and resources should be nationally and internationally recognizable and competitive; hence Lanzarote is an interesting case in point for achieving the goals of this study. 


\section{Immigration and destination competitiveness in tourism}

As competition increases, destinations strive to attract and retain tourists. The success of tourism destinations in world markets depends on their relative competitiveness (Enright \& Newton, 2004). Consequently, destination competitiveness has become a major topic in tourism literature. Based on Enright and Newton (2004), destination competitiveness can be defined as the degree to which a destination can attract and satisfy potential tourists. Pike (2008) extends the concept, referring to a balance between an effective market position, profitable tourism businesses, an attractive environment, positive visitor experiences and supportive local residents. Island destinations also compete in world or regional markets, and their competitiveness can be even more relevant due to the lack of land transportation with neighbour markets.

Destinations offer experiences to tourists. These experiences are key for competitiveness, and various agents interact to offer them: firms that offer tourism services or supporting activities, destination management organizations, public administrations, local residents, and other publics (Crouch, 2010). The variety of these agents and the interaction with visitors and the resources available in the destination comprise a complex network that offers the tourist product.

The classical concept of immigration addresses the long-term change of residence from one country to another. Schaeffer and Kahsai (2011) indicate that lax enforcement of visa rules and national borders, along with a very long waiting line (e.g., small annual quotas) for immigrant visas, can make illegal immigration a preferred option over legal immigration. Scholars have debated whether illegal immigrants contribute positively or negatively to the host countries (e.g., Nadadur, 2009). As immigrants-especially illegal ones-have a worse outside option than natives, their wages are lower, and consequently their presence reduces the labour costs of employers (Chassamboulli \& Peri, 2015) which results in firms that are more costcompetitive. Nadadur (2009) finds that when considering fiscal impacts, it appears that illegal immigrants are a net fiscal cost, since they receive more in publicly provided social services (e.g., health care, education, and incarceration) than they pay for in taxes. However, this author states that illegal immigrants also positively contribute to the US economy as consumers in the market. Comparing legal and illegal immigration, Chassamboulli and Peri (2015) advocate that policies which decrease the number of illegal immigrants but increase the total number of immigrants (such as legalization) will improve job creation, decrease native unemployment, and increase income per native.

In some social contexts, a popular perception is that illegal immigration causes higher crime rates. Ousey and Kubrin (2009) indicate that findings on the relationship between immigration and criminality generally contradict the popular belief that immigrants are particularly crime prone, especially regarding first-generation immigrants. According to Rumbaut (2008), the problem of crime and incarceration in the United States is not generated or even aggravated by immigrants, regardless of their legal status.

There is a close relationship between tourism and immigration (e.g., Feng \& Page, 2000; Cànoves Valiente \& Blanco Romero, 2009), since many tourism activities in developed countries demand immigrant workers and this influx generates tourism flows, in particular in order to visit friends and relatives (e.g., Lehto et al., 2001). The growth of tourism has generated two different flows of migration (Williams \& Hall, 2000a): the labour force required to provide the services for the tourists, and the consumption-led migration (second home tourists, retirees, etc.). Although this last form of migration is abundant in Southern European islands that host an increasing number of nationals from countries in Northern and Central Europe, it is not very controversial in tourism destinations as these kinds of migrants tend to be affluent (or at least with a secured income) and do not compete for jobs with locals. However, traditional 
immigration composed of job-seekers is much more controversial in certain geographical areas, especially when unskilled immigrants are considered. The exception could be senior management and expatriate managers, who migrate often as a consequence of the internationalization of the capital in the tourism industry (Williams \& Hall, 2000b), and some skilled workers who perform 'difficult' or exotic tasks in their jobs (e.g., chefs) and young travelers who work as part of a longer travelling experience.

In highly developed islands where tourism is a relevant economic activity, or when islands with significant tourism activities achieve a higher level of development, many jobs in the tourism industry prove unattractive to locals. This has been the case in Spain, and it presents an opportunity for immigrants who can fill these positions. Moreover, Williams and Hall (2000b, p. 11) state that "the scale and speed of destination and resort growth has implications on the dependence on migrants as opposed to local labor." These authors also refer to the development of new centres of mass tourism consumption rooted in areas of low population density but with the required attractions, such as some points along the Mediterranean coastline, which become magnets for immigration. In addition, tourism, as a means of coming into contact with a territory, can be even a pre-immigration facilitator (Oigenblick \& Kirschenbaum, 2002). At the same time, immigration unleashes a complex pattern of tourism activities in the medium and long term.

The growing competitiveness of destinations and businesses can even make foreign skill a necessity (e.g., Aitken \& Hall, 2000). As has been addressed above, but with emphasis on costs, Cànoves Valiente and Blanco Romero (2009) add that in Spain the arrival of immigrants drives down wages and that foreign workers tend to earn $30 \%$ less than natives in this country. The paradox is that while in the tourism industry immigration is generally welcome as it provides necessary labour, some political discourses are oriented toward highlighting the negative effects it produces (Cànoves Valiente \& Blanco Romero, 2009).

In order to build a model of destination competitiveness, Zhang, Gu, Gu, and Zhang (2011) observe three possibilities in their literature review: to focus on the destination image or attractiveness level, to focus on Porter's (1990) diamond framework, or to use a combination of both approaches. In this study, we have opted for the destination image or attractiveness perspective, with reference to reputation. This allows us to focus on the demand side while integrating the powerful explanatory frameworks of the resource- and knowledge-based views.

\section{Destination competitiveness, reputation, and knowledge}

Reputation is considered an intangible resource. A positive reputation is critical because of its potential to create value, but also because its intangible character makes replication by competing destinations or firms considerably more difficult (Roberts \& Dowling, 2002). Reputation has been analyzed in the tourism field mostly from the economic perspective (e.g., Claude \& Zaccour, 2009), assuming that tourists base their decisions and expectations of quality on the destination's reputation and that this factor is then key for its development and competitiveness.

Extrapolating from Fombrun's (1996) ideas, reputation in the destination context can be defined as the perceptual representation of a destination's past actions and future prospects that describes its overall appeal to all of its key constituents when compared with leading rivals. It is the "beliefs and evaluations held by external audience members" (Fischer \& Reuber, 2007, p. 55) and it can be linked to stakeholders' perceptions about an island destination's ability to create value relative to competitors. A deeper approach to the concept could be taken by extracting three dominant aspects in the definitions used in the management field (Lange et al., 2011): familiarity with the destination, beliefs about what to expect from the destination in the future and the experiences it can provide, and impressions about the destination's favourability. 
Reputation could be then associated to insular competitiveness since a positive reputation makes an island more attractive to investors, employees, and tourists.

As the efforts at enhancing reputation are clearly linked to the brand, the demand perspective is key. The impact of the media on influencing travel behaviour as well as tourism policy is highlighted in the literature (e.g., Hall, 2002). In fact, the evolution of a destination's reputation over time could partially explain the stagnation and decline of destinations (Claude \& Zaccour, 2009) or could foster their development. For Gartner (1994), the process of image formation is intricately entwined with the destination selection process, and, hence, its reputation is key for tourists' travel decisions. Destination image measurement has been one of the most popular tourism fields for assessing marketplace competitiveness (Pike \& Mason, 2011). Extrapolating from Fetscherin's (2010) ideas, a strong island brand could attract tourism and immigration as well.

Leseure (2014) indicates that most island jurisdictions have participated in some forms of nation branding between 2002 and 2012, and consequently the topic has become an active line of research. Moreover, symbiotic relationships between islands in an archipelago or collection of islands may also be used on the packaging of the archipelago as a site for touristic experience (Johnson, 2016). Grydeh $\varnothing \mathbf{j}$ (2008) asserts that island brands, and hence reputation, need to be developed out of their own cultural and geographical contexts. The notion of islandness can be used in order to act as a general brand framework, not only for tourism purposes but also to embed authenticity in the island's goods (Johnson, 2012). This islandness could be seen as the unique intangible underlying area of origin equity "which should be released through a branding process for the sake of economic benefits" (Leseure, 2014, p. 345). Islands have become "the objects of what may be the most lavish, global and consistent branding exercise in human history" (Baldacchino, 2013, p. 14) and their image often reflects the attributes of idyllic, paradisiacal places. Thus, instead of the island identity as conceived and interpreted by their inhabitants (Grydehøj, 2008), some island-based destination management organisations can be tempted to present a different image which is not linked to local culture. Though island inhabitants frequently ensure and reinforce the positive clichés and stereotypes associated with the island image (Baldacchino, 2013), they cannot be forced to conform to an externally designed brand which diverges from their beliefs (Grydeh $\varnothing \mathbf{j}, 2008$ ). Many islands have used real or even invented aspects of their heritage as part of their imagemaking efforts (Johnson, 2012).

A relevant aspect for this research is how island reputation/image is created and changed. The image-formation process has been an area of inquiry for more than 40 years (e.g., Gartner, 1994). Gartner (1994) underlines the relevance of awareness in the destination image field, since awareness implies that an image of the destination exists in the minds of decisionmakers. The knowledge-based perspective thus offers an interesting approach to understanding the image-making process. Knowledge can be defined as justified true belief (Nonaka \& Takeuchi, 1995) or "information that is relevant, actionable, and based at least partially on experience" (Leonard \& Sensiper, 1998, p. 113). Nonaka and Takeuchi (1995) affirm that two aspects can be distinguished in the concept of knowledge: the knowledge that can be transmitted through a systematic language (i.e., explicit knowledge), and mental schemes, beliefs, and perspectives, which the human being uses to perceive and define the environment, along with abilities, skills, or know-how to perform specific tasks (i.e., tacit knowledge). In the reputation analysis, different knowledge sources contribute to the formation of a country (or regional) brand in the consumer's mind, such as education, access to information, frequency of travel, and exposure to other cultures (Paswan \& Sharma, 2004). In this sense, the media, friends' and relatives' opinions, past travel experience, etc., also contribute to the development of destination reputations and preferences held by the tourist. 


\section{Research methodology}

The present study involved a survey of foreign and domestic tourists departing from the island of Lanzarote. The survey was conducted while tourists were waiting for their flights. The sample was taken at random at Lanzarote Airport, and a system of quotas relative to nationality was established to assure the representativeness of visitors to the island.

The questionnaire included questions to address the three research goals. One group of questions dealt with aspects of the arrival of immigrants, including news in the media about immigration to the island, and they were formulated on a 5-point Likert scale. Another category addressed the level of contact with immigrants from the major geographical regions of the world with a relevant presence on the island, also on a 5-point Likert scale. One question about the ability to assess the number of immigrants on the island was also prepared, and two questions aimed to establish the perception of the number of European and non-European immigrants on Lanzarote among those tourists who felt confident to answer. These three questions were formulated on a 5-point Likert scale.

Another category of items was included in the questionnaire to address the level of satisfaction with dimensions of competitiveness during the visit to Lanzarote as well as the positive/negative influence that the presence of immigrants could have on these aspects. All the items in this category had a 7-point Likert format. The existing literature provided much inspiration on the dimensions of competitiveness to include in the questionnaire with respect to the positive or negative impact of immigration as stated in various pieces of research (e.g., Aitken \& Hall, 2000). Moreover, we reviewed traditional dimensions of competitiveness subject to a possible influence by immigration.

A total of 359 valid questionnaires were obtained. Regarding the sample, $52.6 \%$ of respondents are women. Most respondents are between 26 and 35 years old (39.9\%) and between 36 and 45 years old (28\%). Respondents with secondary education $(43.5 \%)$ or a bachelor's degree $(31 \%)$ are the most relevant education categories. The main nationality represented in the sample is British (43\%), followed by Spaniards (20\%), and German and Austrians (17.3\%). For $61.8 \%$ of respondents, this was their first visit to the island. This is in line with the nationality distribution of tourists in the month before the beginning of the fieldwork and used for the system of quotas. Among the total number of tourists, the percentage of British tourists was largest (42.68\%), followed by Spaniards $(21.81 \%)$ and German and Austrians combined (16.60\%). Assuming a 95\% confidence level, and adopting the prudent approach of considering the number of tourists across the whole year as the population, the study has a $5.2 \%$ margin of error.

\section{Results}

The first empirical goal of this study is to analyze the knowledge about news and information on immigration at a destination, since this can be a major factor in the creation of image and reputation at a destination. Major European television networks, radio stations and newspapers from inbound tourism markets (e.g., BBC, RTE radio, Süddeutsche Zeitung, and The Guardian) reported on the arrival of immigrants to the Canaries by sea in the late 2000s. Those news sources commented on many aspects of the immigration process, especially the quantity of illegal immigrants, the journey on boats, and interceptions by Spanish authorities. Thus, the news described the arrival of most immigrants packed into narrow, open boats on journeys which sometimes took weeks, as well as on the arrival of bigger ships, such as an ocean-going 
African fishing boat carrying 229 migrants. The media also echoed that hundreds of would-be illegal immigrants had died en route.

Table 1 displays the results of the survey regarding tourists' knowledge about the arrival of immigrants to the islands and the problems and measures taken by the government to tackle these problems. At a time when domestic and international media in Europe significantly reported the effects and impacts of the arrival of immigrants by sea to the Canary Islands, tourists seem poorly informed about these topics. The fact that such immigration was occurring nevertheless seems to have been noticed and recalled by a significant number of tourists, since $60.8 \%$ of them acknowledge having very little or some knowledge of the immigrants' arrival, and $13.7 \%$ have more solid knowledge about it. The fact that this arrival was by sea with the risk of shipwreck, hunger, and thirst was also grasped by many tourists. In this sense, $70 \%$ of the respondents had been exposed to and retained some information about the death and hardship of immigrants at sea.

Table 1: Tourists' knowledge about news on immigration on Lanzarote.

\begin{tabular}{||l|c|c|c|c|c|c||}
\hline \multirow{2}{*}{$\begin{array}{c}\text { ASPECTS RELATED TO THE } \\
\text { ARRIVAL OF IMMIGRANTS }\end{array}$} & \multirow{2}{*}{$\mathrm{N}$} & \multicolumn{5}{|c||}{ LEVEL OF KNOWLEDGE } \\
\cline { 5 - 8 } & & Nothing & Very little & Some & Quite a lot & $\begin{array}{c}\text { A great } \\
\text { deal }\end{array}$ \\
\hline Arrival of immigrants in small boats & 357 & $25.5 \%$ & $42.6 \%$ & $18.2 \%$ & $9.2 \%$ & $4.5 \%$ \\
\hline Death and hardship at sea & 357 & $30.0 \%$ & $38.4 \%$ & $17.4 \%$ & $10.9 \%$ & $3.4 \%$ \\
\hline Relocation of immigrants to other zones & 357 & $66.9 \%$ & $14.8 \%$ & $5.9 \%$ & $9.2 \%$ & $3.1 \%$ \\
\hline Repatriation operations to home countries & 356 & $47.2 \%$ & $30.9 \%$ & $11.2 \%$ & $8.4 \%$ & $2.2 \%$ \\
\hline Naturalization of immigrants & 356 & $70.5 \%$ & $11.0 \%$ & $9.6 \%$ & $8.4 \%$ & $0.6 \%$ \\
\hline Impact/conflict with local population & 356 & $72.8 \%$ & $12.1 \%$ & $8.7 \%$ & $5.3 \%$ & $1.1 \%$ \\
\hline $\begin{array}{l}\text { Humanitarian problems on the islands } \\
\text { (overcrowded detention centres, etc.) }\end{array}$ & 356 & $74.4 \%$ & $9.0 \%$ & $8.1 \%$ & $7.9 \%$ & $0.6 \%$ \\
\hline
\end{tabular}

The rest of the news with regard to measures taken to deal with illegal immigration, and the impact on the local population and the problems of their stay on the islands, show significantly lower data of exposure and retained knowledge. This is reflected in the data that show that two-thirds or more of the individuals in the sample knew nothing about realities such as the relocation of immigrants to other zones in Spain, the naturalization of immigrants, the impact on and the opposition of the local population, and the humanitarian problems on the islands including the overcrowding of detention centres. The exception to this tendency could be the repatriation operations to home countries: slightly more than half of the surveyed tourists expressed that they knew at least something about it.

The second objective of this study was to analyze the contact tourists had with foreigners at a destination as another key aspect of the reputation-building process. Two different kinds of data were analyzed. The first group of data deals with the level of contact that tourists had during their visit with individuals from other European countries (excluding Spain) and from the world zones which provide the highest number of immigrants to Lanzarote. The other data obtained with regard to this goal addressed the tourists' perception of their ability to assess the number of immigrants present on the island and the consideration of Lanzarote as a destination with an image characterized by a high level of immigration.

The degree of contact with people at the destination is relevant for the tourism experience and becomes a major factor in the on-site reputation-building process. Though the tourists' recognition patterns of immigrants may be inexact and biased, the interest of this study focuses on subjective perceptions because they are key in the creation of reputation and image. The data about the tourists' degree of contact with immigrants are displayed in Table 2. Tourists on Lanzarote are exposed to people from many European countries, such as fellow tourists and foreigners working on the island. In fact, more than $70 \%$ had a medium or higher level of contact with individuals from other European countries. Nevertheless, the tourists' contact with 
non-European immigrants is generally very limited. The relationships with Latin Americans and Africans are very scarce as data show that around $70 \%$ of the tourists had only low contact with them. The exception in this trend may be the contact with people from other parts of the world, which rises to $40 \%$ considering those tourists who had a significant (medium, high, or very high) level of contact. This can mainly be linked to the presence of Asians on the island.

Table 2: Tourists' contact with immigrants on Lanzarote.

\begin{tabular}{|l|c|c|c|c|c|c||}
\hline \hline \multirow{2}{*}{ CONTACT WITH INMIGRANTS } & \multirow{2}{*}{$\mathrm{n}$} & \multicolumn{5}{|c|}{ DEGREE OF CONTACT } \\
\cline { 5 - 8 } & & $\begin{array}{c}\text { Non- } \\
\text { existent }\end{array}$ & Low & Medium & High & Very high \\
\hline $\begin{array}{l}\text { People from other European countries, } \\
\text { excluding Spain }\end{array}$ & 359 & $4.5 \%$ & $24.2 \%$ & $30.1 \%$ & $40.7 \%$ & $0.6 \%$ \\
\hline People from Latin America & 359 & $3.9 \%$ & $74.7 \%$ & $19.2 \%$ & $1.9 \%$ & $0.3 \%$ \\
\hline People from North Africa & 359 & $12 \%$ & $75.8 \%$ & $10.9 \%$ & $1.4 \%$ & $0 \%$ \\
\hline People from Sub-Saharan Africa & 359 & $20.3 \%$ & $69.9 \%$ & $8.4 \%$ & $1.4 \%$ & $0 \%$ \\
\hline People from other parts of the world & 359 & $11.1 \%$ & $50.1 \%$ & $35.4 \%$ & $3.1 \%$ & $0.3 \%$ \\
\hline \hline
\end{tabular}

Table 3 presents the tourists' perception of their ability to assess the number of immigrants on Lanzarote as well as their perceptions of whether the island has a reputation associated with immigration and the number of immigrants (taking into account only those tourists who had enough self-confidence to express an opinion on this topic).

\section{Table 3: Tourists' perception of their ability to assess the number of immigrants on} Lanzarote and perception of the actual number of immigrants.

\begin{tabular}{||l|c|c|c|c||}
\hline $\begin{array}{c}\text { PERCEPTION OF THE ABILITY TO ASSESS THE } \\
\text { NUMBER OF IMMIGRANTS ON LANZAROTE }\end{array}$ & $\mathrm{N}$ & $\begin{array}{c}\text { Not } \\
\text { possible to } \\
\text { assess it }\end{array}$ & $\begin{array}{c}\text { Low or } \\
\text { medium }\end{array}$ & $\begin{array}{c}\text { High or } \\
\text { very high }\end{array}$ \\
\hline Self-confidence to assess the number of immigrants on the island & 357 & $55.2 \%$ & $36.4 \%$ & $8.4 \%$ \\
\hline $\begin{array}{c}\text { PERCEPTION OF THE NUMBER OF IMMIGRANTS } \\
\text { ON LANZAROTE }\end{array}$ & $\mathrm{N}$ & $\begin{array}{c}\text { Low or } \\
\text { very low }\end{array}$ & Medium & $\begin{array}{c}\text { High or } \\
\text { very high }\end{array}$ \\
\hline Perception of the number of European immigrants & 160 & $1.3 \%$ & $78.8 \%$ & $19.9 \%$ \\
\hline Perception of the number of non-European immigrants & 160 & $3.1 \%$ & $56.3 \%$ & $40.7 \%$ \\
\hline
\end{tabular}

Most tourists concede that they do not have enough information to express a sound opinion on the number of immigrants on the island where they have just spent their vacation. Fewer than $10 \%$ of the visitors reckon that they can give a very informed opinion about the number of immigrants on the island. The remaining $36.4 \%$ of the tourists who ventured to offer a quantitative assessment of the number of immigrants on the island declared a low or medium level of self-confidence.

Tourists who had at least a little self-confidence in expressing an opinion were asked about the number of immigrants, distinguishing between perceptions of European and nonEuropean immigrants. The most frequent value for assessing the numbers of European and nonEuropean immigrants is the medium number of immigrants on the island, showing an overwhelming $78.8 \%$ for the perception of immigrants from European countries, with a lower $56 \%$ for non-Europeans. Consequently, the data about whether or not there is a high number of immigrants on Lanzarote shows a different pattern in the function of these two categories. Thus, $40 \%$ of the visitors declare there is a high or very high number of non-European immigrants, compared to around $20 \%$ who express that perception about European nationals.

The third objective of this study is to analyze the influence of the presence of immigrants at a destination from the demand side's reputational perspective. In order to meet this objective, two different lines of work were followed. In the first line of work, the analysis deals with opinions expressed by the tourists about the negative or positive influence of the presence of non-European immigrants on a wide array of dimensions of destination competitiveness. In the second line of work, we analyzed the relative influence of the perceived level of non-European 
immigration on two key measures of competitiveness (global satisfaction and likelihood to return).

Table 4 summarizes the opinions that tourists express about the influence of the presence of non-European immigrants on a destination. The data input by tourists on the 7-point Likert scales were recomputed to show the value 0 for those situations in which the presence of nonEuropean immigrants exerts a neutral effect on the dimension in question. Thus, the reformulated scales range from -3 (a very negative influence) to 3 (a very positive influence). Table 4 displays values from -3 to -1 in the category Negative or very negative and values from 1 to 3 in the category Positive or very positive.

According to tourists' opinions, the presence of non-European immigrants has no significant effect on Lanzarote's cleanliness and environmental preservation, the cosmopolitism, quality of infrastructures, and image of prestige and excellence since the mean on these dimensions has a value very close to 0 . Regarding significant negative influences of the presence of non-European immigrants (identified with means with a relatively high negative value), tourists are concerned about the impact of immigration on the possibility of offering services to tourists in their own languages as well as security in the destination. Tourists nevertheless express a remarkably positive effect of the presence of non-European immigrants on aspects such as the wide and diverse supply in key services for tourists (accommodation, food and beverages, etc.) and hospitality and friendliness in the services offered. A positive influence is also identified in the dimensions concerning the availability of labour for tourism services, innovation, and creation of new products in the tourism industry, and consolidation of relatively low prices at the destination.

Table 4: Tourists' opinions about the influence of the presence of non-European immigrants on a destination.

\begin{tabular}{|l|c|c|c|c|c||}
\hline \multicolumn{1}{|c|}{ DIMENSIONS OF COMPETITIVENESS } & \multirow{2}{*}{$\mathrm{N}$} & Mean & \multicolumn{3}{|c|}{$\begin{array}{c}\text { INFLUENCE OF THE PRESENCE OF } \\
\text { NON-EUROPEAN IMMIGRANTS }\end{array}$} \\
\cline { 4 - 7 } & $\begin{array}{c}\text { Negative or } \\
\text { very negative }\end{array}$ & $\begin{array}{c}\text { No significant } \\
\text { influence }\end{array}$ & $\begin{array}{c}\text { Positive or } \\
\text { very positive }\end{array}$ \\
\hline Local traditions and cultural aspects (folklore, cuisine, etc.) & 359 & 0.22 & $23.4 \%$ & $35.9 \%$ & $40.7 \%$ \\
\hline Cleanliness and environmental preservation & 359 & 0.02 & $27.0 \%$ & $42.6 \%$ & $30.4 \%$ \\
\hline The landscape and protection of the territory & 358 & 0.11 & $23.7 \%$ & $41.3 \%$ & $35.0 \%$ \\
\hline $\begin{array}{l}\text { A wide and diverse supply in services of accommodation, } \\
\text { restaurants, and leisure }\end{array}$ & 359 & 1.18 & $10.6 \%$ & $13.6 \%$ & $75.8 \%$ \\
\hline The possibility to interact with local people & 359 & -0.18 & $30.6 \%$ & $52.1 \%$ & $17.3 \%$ \\
\hline $\begin{array}{l}\text { The possibility of offering services to tourists in their own } \\
\text { languages }\end{array}$ & 359 & -0.42 & $51.0 \%$ & $31.8 \%$ & $17.2 \%$ \\
\hline $\begin{array}{l}\text { Whether a destination is considered international and } \\
\text { cosmopolitan }\end{array}$ & 359 & 0.02 & $20.3 \%$ & $56.3 \%$ & $23.4 \%$ \\
\hline Having plenty of labour for tourism services & 358 & 0.94 & $10.6 \%$ & $18.2 \%$ & $71.2 \%$ \\
\hline $\begin{array}{l}\text { Workers' qualification and professionalism in the tourism } \\
\text { industry }\end{array}$ & 359 & 0.28 & $20.9 \%$ & $36.2 \%$ & $42.9 \%$ \\
\hline $\begin{array}{l}\text { Innovation and creation of new things to offer in the tourism } \\
\text { industry }\end{array}$ & 359 & 0.76 & $12.5 \%$ & $27.6 \%$ & $59.9 \%$ \\
\hline The relatively low price of the tourism services available & 359 & 0.67 & $13.1 \%$ & $21.4 \%$ & $65.5 \%$ \\
\hline Security at the destination & 359 & -0.40 & $48.2 \%$ & $37.0 \%$ & $14.8 \%$ \\
\hline $\begin{array}{l}\text { Quality of the infrastructure related with tourism activities } \\
\text { and its use (hospitals, roads, etc.) }\end{array}$ & 359 & 0.09 & $25.6 \%$ & $37.9 \%$ & $36.5 \%$ \\
\hline Hospitality and friendliness in the services offered & 359 & 1.03 & $10.9 \%$ & $12.8 \%$ & $76.3 \%$ \\
\hline The image of prestige and excellence of the destination & 359 & 0.03 & $18.4 \%$ & $54.0 \%$ & $27.6 \%$ \\
\hline
\end{tabular}

The other analytical path in this third objective deals with the relative influence of the perceived quantity of non-European immigrants on global satisfaction with the destination and its ability to retain tourists, measured as the likelihood to return. This influence was observed with the results of ordered probit regression analyses on both variables. In order to follow a global approach, the explanatory variables included in these regression models were perceived 
satisfaction with the dimensions of competitiveness shown above during the visit to Lanzarote, the perceived quantity of non-European immigrants, and some control variables.

An exploratory factor analysis was first conducted to reduce the dimensionality of the variables regarding satisfaction with the different aspects of competitiveness. Four factors of satisfaction with the different dimensions of competitiveness for Lanzarote were obtained. The first factor retains significant information from traditional attractions and advantages of destinations (such as culture and low prices) and from modern and dynamic dimensions of attractiveness (innovation, comprehensive supply of activities, cosmopolitism, etc.). We will refer to this factor as satisfaction with traditional and dynamic attractions of the destination. The second factor (satisfaction with professionalism in the tourist activities) extracts information from items related to the qualification and adequacy of the tourism activities. The third factor refers to the satisfaction with social aspects. Finally, the fourth factor is mainly made up by two variables related to the environment, and can be named satisfaction with environmental aspects.

The results of the ordered probit regression analysis on global satisfaction with the visit to Lanzarote are presented in Table 5, and Table 6 shows the results for the regression model on the likelihood to return to the island. It is important to note that all of these analyses have been conducted by only considering the tourists who expressed their quantitative perception of non-European immigrants on the island and who had previously declared that they had at least some level of self-confidence to offer an opinion about it.

Table 5: Ordered probit regression on satisfaction with the visit (Model 1).

\begin{tabular}{|c|c|c|c|}
\hline \multirow{2}{*}{ VARIABLES } & \multicolumn{3}{|c|}{ Satisfaction with the visit } \\
\hline & Coefficient & $\mathbf{Z}$ & $\mathbf{P}>|\mathbf{z}|$ \\
\hline Satisfaction with trad. \& dynamic attractions & -0.0221458 & -0.25 & 0.801 \\
\hline Satisfaction with professionalism & 0.3183931 & 3.50 & 0.000 \\
\hline Satisfaction with social aspects & -0.1361088 & -1.73 & 0.084 \\
\hline Satisfaction with environmental aspects & 0.0475529 & 0.51 & 0.611 \\
\hline Number of immigrants on the island (perception) & 0.1686582 & 2.15 & 0.031 \\
\hline Gender (male) & 0.278243 & 1.47 & 0.142 \\
\hline Age (young) & -0.0455223 & -0.23 & 0.817 \\
\hline University degree & 0.042479 & 0.21 & 0.836 \\
\hline Employed & -0.4203079 & -1.46 & 0.145 \\
\hline First visit to the destination & 0.0137468 & 0.07 & 0.946 \\
\hline $\begin{array}{r}\text { Pseudo R } \\
\end{array}$ & \multicolumn{3}{|c|}{0.0673} \\
\hline $\mathrm{N}$ & \multicolumn{3}{|c|}{147} \\
\hline
\end{tabular}

Table 6: Ordered probit regression on satisfaction with the visit (Model 2).

\begin{tabular}{|c|c|c|c|}
\hline \multirow{2}{*}{ VARIABLES } & \multicolumn{3}{|c|}{ Satisfaction with the visit } \\
\hline & Coefficient & $\mathbf{z}$ & $\mathbf{P}>|\mathbf{z}|$ \\
\hline Satisfaction with trad. \& dynamic attractions & 0.1139569 & 1.31 & 0.192 \\
\hline Satisfaction with professionalism & 0.3383077 & 3.96 & 0.000 \\
\hline Satisfaction with social aspects & -0.0812666 & -1.05 & 0.292 \\
\hline Satisfaction with environmental aspects & 0.2300136 & 2.47 & 0.014 \\
\hline Number of immigrants on the island (perception) & 0.2878108 & 3.78 & 0.000 \\
\hline Gender (male) & -0.2526801 & -1.37 & 0.172 \\
\hline Age (young) & -0.0548714 & -0.29 & 0.774 \\
\hline University degree & -0.0302586 & -0.15 & 0.880 \\
\hline Employed & -0.3278031 & -1.15 & 0.248 \\
\hline First visit to the destination & -0.3934369 & -1.97 & 0.048 \\
\hline Pseudo $\mathrm{R}^{2}$ & \multicolumn{3}{|c|}{0.1048} \\
\hline $\mathrm{N}$ & \multicolumn{3}{|c|}{147} \\
\hline
\end{tabular}

As data in Table 5 show and considering a level of significance of $5 \%$, the number of non-European immigrants exerts a positive influence on the global satisfaction with the visit to the island, along with satisfaction with the professionalism of the employees in tourism activities on the island. Table 6 shows that the likelihood to return to Lanzarote is also explained by the 
perceived number of non-European immigrants as well as two factors associated with satisfaction with competitiveness dimensions (the one about professionalism in the tourist activities and the one about environmental aspects). The fact that this was not the first visit to Lanzarote for the tourist becomes another significant determinant of the likelihood to return to the island.

\section{Conclusion}

Immigration is becoming a paramount element for competitiveness (Huber et al., 2010), and at the same time it is a controversial issue in some social and political contexts. In recent decades, the tourism industry has witnessed the presence of many immigrants that come to the industry to perform activities where the available local labour force supply is limited. This study provides an exploratory contribution to immigration and destination competitiveness on islands by analyzing the demand perspective.

The reputation of an island destination is configured by knowledge stemming from several sources. Despite the media coverage in several countries across Europe about the arrival, problems, and political decisions concerning immigrants in several European regions, the results obtained with the data from an island with a high percentage of immigrants in its population show the relatively low impact and retention of this news on the average tourist. Information about the arrival of non-European immigrants and the problems they encounter during the journeys from their home countries has reached most tourists, and the repatriation operations to home countries are also relatively well known. However, aspects concerning other measures to deal with illegal immigration, and the impact on the local population and the problems connected with their stay on the islands, were less clearly retained by a significant share of tourists. This evidences the apparent misguidedness of certain political analyses about the overexposure of certain destinations in the media regarding the impact on the main incoming tourism markets.

The level of contact and interaction with immigrants at the destination is another source for creating knowledge on and building the reputation of a destination on immigration-related attributes. As the gathered data have shown, most tourists seem not to have a significant amount of contact with immigrants when visiting the island. Even when the labour force for the hospitality industry and other tourism activities comes from immigrant communities to the island, tourists only tend to perceive high levels of contact with other Europeans.

As for the perception of the number of non-European immigrants on the island, most tourists concede they are unable to provide a quantitative assessment. Self-confidence to assess the number of immigrants on the island was thus not possible for most tourists. This is relevant for defining the perception of whether an island destination can have a reputation associated with its being an immigration territory. A significant share of tourists may be enjoying the attractions and leisure possibilities of a destination without paying attention to social issues that could be part of the political debate in their home countries and regions. For those tourists who express enough self-confidence to evaluate the number of immigrants, most tend to consider that the number is medium/average.

The effects of destination reputation linked to a place's status as an immigration territory and its impact on competitiveness is becoming a topic of interest in destination management, especially in island destinations. From the demand perspective, tourists tend to recognize the positive value created by the influx of non-European immigrants to a destination in aspects such as the support, variety, innovation, and cost of the tourism services on offer as well as variables related to interpersonal contact (hospitality and friendliness). According to the tourists, the negative effect of that migrant influx would involve the possibility of interacting in the tourists' own languages and safety at the destination. 
The positive influence that immigrants can have on a destination may be a reason to state that perception of the number of non-European immigrants has a positive impact on tourists' global satisfaction and loyalty to the destination, at least for those tourists who consider themselves capable of giving a quantitative estimate of immigrants at the destination. For those tourists, both measurements of destination competitiveness are significantly and positively explained by the perceived number of immigrants, suggesting a high level of knowledge and insight by the average tourist in this category. Although negative views have tended to persist despite the argument that immigration can entail many positive economic benefits for the host country (Drinkwater, 2010), these negative perspectives may dissolve in a tourism environment where positive experiences outweigh the negative ones. Since tourism is essentially rooted in exposure to unfamiliar situations (Franklin, 2003), tourists can judge and assess situations in the island destination in accordance with different parameters to the ones they use in their local environment. Hence, tourists can see immigration in a destination as a required facilitator of the whole tourism infrastructure, thereby overcoming the mental barriers linked to the dangers of 'inauthenticity'.

Regarding the lessons that island politicians could extract from these findings, perhaps the most important one is that immigration does not necessarily hinder the development of an island's tourism sector; on the contrary, it may strengthen its competitiveness, at least from the tourists' perspective. Political activity should stress that tourists may be very unconcerned about immigration in the places they visit, and they may find more advantages in it than drawbacks regarding satisfaction and the possibility of visiting the region again.

\section{References}

Aitken, C., \& Hall, M.C. (2000). Migrant and foreign skills and their relevance to the tourism industry. Tourism Geographies, 2(1), 66-86. https://doi.org/10.1080/146166800363457

Akee, R. (2010). Who leaves? Deciphering immigrant self-selection from a developing country. Economic Development and Cultural Change, 58(2), 323-344. https://doi.org/10.1086/647978

Alvarez Alonso, A., Hernández Hernández, J., \& Simancas Cruz, M.R. (2005). Transformaciones recientes en la distribución territorial de la población de Canarias. Cuadernos Geográficos, 36(1), 349-360.

Baldacchino, G. (2014). Islands and offshoring possibilities and strategies of contemporary states: insights on/for the migration phenomenon on Europe's southern flank. Island Studies Journal, 9(1), 57-68.

Baldacchino, G. (2013). Island landscapes and European culture: An 'island studies' perspective. Journal of Marine and Island Cultures, 2(1), 13-19.Bauer, T., Lofstrom, M., \& Zimmermann, K.F. (2000). Immigration policy, assimilation of immigrants, and natives' sentiments towards immigrants: evidence from 12 OECD countries. Swedish Economic Policy Review, 7(2), 11-53.

Beerli, A., \& Martín, J. (2004). Tourists' characteristics and the perceived image of tourist destinations: a quantitative analysis - a case study of Lanzarote, Spain. Tourism Management, 25(5), 623-636. https://doi.org/10.1016/j.tourman.2003.06.004

Bernardie-Tahir, N., \& Schmoll, C. (2014). The uses of islands in the production of the southern European migration border. Island Studies Journal, 9(1), 3-6.

Cànoves Valiente, G., \& Blanco Romero, A. (2009). Turismo, mercado de trabajo e inmigración en España. Un análisis de la situación en las Comunidades de Murcia, Canarias, Valencia y Andalucía. Boletín de la A.G.E., 50, 259-280. 
Chassamboulli A., \& Peri, G. (2015). The labor market effects of reducing the number of illegal immigrants. Review of Economic Dynamics, 18, 702-821. https://doi.org/10.1016/j.red.2015.07.005

Chen, C.M., Chen, S.H., \& Lee, H.T. (2011). The destination competitiveness of Kinmen's tourism industry: Exploring the interrelationships between tourist perceptions, service performance, customer satisfaction and sustainable tourism. Journal of Sustainable Tourism, 19(2), 247-264. https://doi.org/10.1080/09669582.2010.517315

Claude, D., \& Zaccour, G. (2009). Investment in tourism market and reputation. Journal of Public Economic Theory, 11(5), 797-817. https://doi.org/10.1111/j.14679779.2009.01430.x

Crouch, G.I. (2010). Destination competitiveness: An analysis of determinant attributes. Journal of Travel Research, 50(1): 27-45. https://doi.org/10.1177/0047287510362776

Drinkwater, S. (2010). Immigration and the economy. National Institute Economic Review, 213, R1-R4. https://doi.org/10.1177/0027950110380319

Enright, M.J., \& Newton, J. (2004). Tourism destination competitiveness: A quantitative $\begin{array}{llll}\text { approach. Tourism } & \text { Management, } & \text { 777-788. }\end{array}$ https://doi.org/10.1016/j.tourman.2004.06.008

Feng, K., \& Page, S.J. (2000). An exploratory study of the tourism, migration-immigration nexus: Travel experiences of Chinese residents in New Zealand. Current Issues in Tourism, 3(3), 246-281. https://doi.org/10.1080/13683500008667875

Fetscherin, M. (2010). The determinants and measurement of a country brand: The country brand strength index. International Marketing Review, 27(4), 466-479. https://doi.org/10.1108/02651331011058617

Figueroa, E., \& Rotarou, E. (2016). Tourism as the development driver of Easter Island: the key role of resident perceptions. Island Studies Journal, 11(1), 245-264.

Fischer, E., and Reuber, R. (2007). The good, the bad, and the unfamiliar: The challenges of reputation formation facing new firms. Entrepreneurship: Theory and Practice, 31(1), 53-75. https://doi.org/10.1111/j.1540-6520.2007.00163.x

Fombrun, C.J. (1996). Reputation. Realizing value from the corporate image. Boston MA: Harvard Business School Press.

Franklin, A. (2003). Tourism: An introduction. London UK: Sage. https://doi.org/10.4135/9781446220108.n2

García-Rodríguez, J.L., García-Rodríguez, F.J., \& Castilla-Gutiérrez, C. (2016). Human heritage and sustainable development on arid islands: the case of the Eastern Canary Islands. Island Studies Journal, 11(1), 113-130.

Gartner, W.C. (1994). Image formation process. Journal of Travel and Tourism Marketing, 2(23), 191-216. https://doi.org/10.1300/J073v02n02_12

Godenau, D. (2012). An institutional approach to bordering in islands: The Canary Islands on the African- European migration routes. Island Studies Journal, 7(1), 3-18.

Graci, S., \& Dodds, R. (2010). Sustainable tourism in islands destinations. Oxon UK: Earthscan.

Grydehøj, A. (2008). Branding from above: Generic cultural branding in Shetland and other islands. Island Studies Journal, 3(2), 175-198.

Hall, C.M. (2002). Travel safety, terrorism and the media: The significance of the issueattention cycle. Current Issues in Tourism, 5(5), 458-466. https://doi.org/10.1080/13683500208667935

Huber, P., Landesmann, M., Robinson, C., \& Stehrer, R. (2010). Migrants' skills and productivity: A European perspective. National Institute Economic Review, 213, R20R34. https://doi.org/10.1177/0027950113803222 
Johnson, H. (2016). A tale of two Guernseys: Tourism branding and island hopping in an archipielagic context. In Baldacchino, G. (ed.) Archipelago Tourism. Policies and Practices. Oxon, UK: Routledge.

Johnson, H. (2012). 'Genuine Jersey': Branding and authenticity in a small island culture. Island Studies Journal, 7(2), 235-258.

King, R. (2009). Geography, islands and migration in an era of global mobility. Island Studies Journal, 4(1), 53-84.

Kozac, M., Baloglu, S., \& Bahar, O. (2010). Measuring destination competitiveness: Multiple destinations versus multiple nationalities. Journal of Hospitality Marketing and Management, 19, 56-71. https://doi.org/10.1080/19368620903327733

Lange, D., Lee, P.M., \& Dai, Y. (2011). Organizational reputation: A review. Journal of Management, 37(1), 153-184. https://doi.org/10.1177/0149206310390963

Lehto, X.Y., Morrison, A.M., \& O'Leary, J. (2001). Does the visiting friends and relatives' typology make a difference? A study of the international VFR market to the United States. Journal of Travel Research, 40, 201-212. https://doi.org/10.1177/004728750104000211

Leonard, D., \& Sensiper, S. (1998). The role of tacit knowledge in group innovation. California Management Review, 40(3), 112-132. https://doi.org/10.2307/41165946

Leseure, M. (2014). Island branding, identity and economic self-discovery: a simulation model. International Journal of Applied Decision Sciences, 7(4), 343-360. https://doi.org/10.1504/IJADS.2014.065220

Nadadur, R. (2009). Illegal immigration: A positive economic contribution to the United States. Journal of Ethnic and Migration Studies, 35(6), 1037-1052. https://doi.org/10.1080/13691830902957775

National Institute of Statistics (2016). Population data and demographic census (several years). Retrieved from: http://www.ine.es/inebmenu/mnu_cifraspob.htm

Nonaka, I., \& Takeuchi, H. (1995). The knowledge-creating company. New York, NY: Oxford University Press.

OBECAN (2008). Empleo en el sector turístico. Canarias 2008. Observatorio de empleo en Canarias.

Oigenblick, L., \& Kirschenbaum, A. (2002). Tourism and immigration: Comparing alternative approaches. Annals of Tourism Research, 29(4), 1086-1100. https://doi.org/10.1016/S0160-7383(02)00023-3

Ousey, G.C., \& Kubrin, C.E. (2009) Exploring the connection between immigration and violent crime rates in U.S. Cities, 1980-2000. Social Problems, 56(3), 447-473. https://doi.org/10.1525/sp.2009.56.3.447

Paswan, A.K., \& Sharma, D. (2004). Brand-country of origin (COO) knowledge and COO image: investigation in an emerging franchise market. Journal of Product \& Brand Management, 13(3), 144-155. https://doi.org/10.1108/10610420410538041

Pike, S., \& Mason, R. (2011). Destination competitiveness through the lens of brand positioning: The case of Australia's Sunshine Coast. Current Issues in Tourism, 14(2), 169-182. https://doi.org/10.1080/13683501003797523

Pike, S. (2008). Destination marketing. An integrated marketing communications perspective. Oxford: Elsevier. Porter, M.E. (1990). The competitive advantage of nations. New York NY: The Free Press.

Roberts, P.W., \& Dowling, G.R. (2002). Corporate reputation and sustained superior financial performance. Strategic Management Journal, 23(12), 1077-1093. https://doi.org/10.1002/smj.274

Rumbaut, R.G. (2008). Undocumented immigration and rates of crime and imprisonment: Popular myths and empirical realities. In Invited Address to the "Immigration 
Enforcement and Civil Liberties: The Role of Local Police" National Conference, Police Foundation, Washington, DC.

Schaeffer, P.V., \& Kahsai, M.S. (2011). A theoretical note on the relationship between documented and undocumented migration. International Journal of Population Research, 2011. https://doi.org/10.1155/2011/873967

Triandafyllidou, A. (2014). Multi-levelling and externalizing migration and asylum: lessons from the southern European islands. Island Studies Journal, 9(1), 7-22.

Williams, A.M. (2013). Mobilities and sustainable tourism: path-creating or path dependent relationships? Journal of Sustainable Tourism, 21(4), 511-531. https://doi.org/10.1080/09669582.2013.768252

Williams, A.M., \& Hall, C.M. (2000a). Guest editorial: Tourism and migration. Tourism Geographies, 2(1), 2-4. https://doi.org/10.1080/146166800363411

Williams, A.M., \& Hall, C.M. (2000b). Tourism and migration: New relationships between production and consumption. Tourism Geographies, 2(1), 5-27. https://doi.org/10.1080/146166800363420

Zhang, H., Gu, C., Gu, L., \& Zhang, Y. (2011). The evaluation of tourism destination competitiveness by TOPSIS \& information entropy: A case in the Yangtze River Delta of China. Tourism Management, 32(2), 443-451. https://doi.org/10.1016/j.tourman.2010.02.007 